\title{
The Birth and Death of the Russian House in the Priargun'ie Three Rivers Region, People's Republic of China (1)
}

\author{
Vladimir Klyaus \\ Institute of World Literature \\ Moscow, Russia
}

\begin{abstract}
\end{abstract}
This article considers the remnants of Russian ritual practices surrounding houses in the Priangun'ie region of China. This region was populated by Russians from the late $19^{\text {th }}$ century on. A large group of immigrants (Russian, Tungus and Buriat) immigrated there from the Transbaikal region of Russia after the establishment of Soviet rule in the early $20^{\text {th }}$ century. The paper examines what remains of Russian traditional practices, how they have been blended with native Chinese traditions, and adapted over time to reflect intermarriage between people of Chinese or Tungus and Russian descent.

Culturological research on the house as a building that reflects in its foundational elements a person's representation of the world and of the self is, in many respects, founded on the ideas of Carl Jung and Oswald Spengler, who defined the house as a reflection of the structure of the individual, containing all of its particularities (Jung 2003), and as a flexible system, reflecting the nature of a person at a particular period of time (Spengler 2009). For the purposes of this research, the latter approach is especially pertinent. "The pro forma house," wrote Spengler, "emerges entirely organically through feelings. Knowledge of it is impossible. Like a nautilus shell, like a bee hive, like a bird's nest, it is internally something that goes without saying, and all the features of the original customs and the forms of existence, of spousal and family life, and of the organization of a tribe have their precise likeness in the layout of the house and in its foundational premises - the canopies, hall, megaron, atrium, courtyard, women's 'half', and gynoecium" (121).

The house, like the individual, passes through birth and death, appears in a given space, and even after it loses its original form, it continues to exist after the departure of its creators. There are hundreds if not thousands of such examples. In fact, any archeological excavation consists of extracting the remnants of buildings from beneath the layers of earth and attempts to reconstruct the life of their inhabitants. In this article, I would like to focus on a situation that is closer to us in time - the appearance and disappearance of Russian villages and Russian houses in the Priargun'ie Three Rivers region.

The Priargun'ie Three Rivers region is a river basin formed by the Gan, Haul, and Derbul Rivers. They flow into the Argun, which is currently administratively included in the Hulunbuir aimag of the Autonomous District of Inner Mongolia in the People's Republic of China, whose administrative center is the city of Ergun (Labdarin/Labudalin). These lands were well known among the Russian Cossacks, who had dispersed across Priargun'ie beginning in the $17^{\text {th }}$ century. Rich in fish, game, and fertile grasslands, Three Rivers de jure belonged to China, but de facto, from the $17^{\text {th }}$ century on, was settled by Transbaikalian Cossacks (both Russians and Tungus people who had received Russian citizenship), who, from the $18^{\text {th }}$ century on, guarded the border with China. 
In the $19^{\text {th }}$ century, Russians already had winter hunting cabins, hay fields, and pastures in the Three Rivers area, and they went there to hunt and fish. After World War I, immigrants from Russia actively began to take over the region. The peak of settlement, however, came during the Civil War years (1919-1921) and with the establishment of Soviet authority in Transbaikal, when many people who disagreed with the new regime (not only Cossacks, but also Priargun'ie peasants, as well as Buriats and the Tungus people) left for the Three Rivers area, hoping to find a peaceful life in China.

The influx of refugees led to the development of large settlements. The economic activity of Russians in the Three Rivers area led to rapid economic development in the region; in addition to the traditional practice of cultivating grain and raising cattle, the new settlers also engaged in hunting, fishing, and foraging. The Three Rivers region became the breadbasket of northern Manchuria and, in particular, one of the main centers for making butter. This situation continued until the 1950s.

The establishment of Communist authority in China in 1945 and the founding of the People's Republic of China led to a great change in the lives of Russians in the Three Rivers area. Starting in the 1950s, there began a mass exodus of Russians back to the USSR and elsewhere. Today in the Three Rivers area, with a few exceptions, there are, as local people say, no "pure Russians" left, but Russian cultural traditions are preserved among the descendants of the mixed (Russian-Chinese and Russian-Tungus) marriages that date from the 1900s to the 1950s. Ethnographic and folkloric materials representing this enduring tradition, gathered from interviews with Russians in the Three Rivers area about their lives and those of their ancestors, allow us to examine the concrete historical process of the birth and death of the house in this region (all interviews were conducted between 2007 and 2009).

The house does not exist without a master, the agent of its construction, its life, and, in the end, its destruction. In the most general terms, the lifetime of the house can be characterized in the following way: 1) the choice of the construction site; 2) building rituals; 3) moving-in rituals; 4) the presence/absence of a "spirit master" for the house and yard who influences the lives of the inhabitants; 5) departure of the residents from the house, during which, as a rule, they "lead out" the spirit master with them; 6) destruction, i.e., the "death" of the house.

The first temporary dwellings of Russians in the Three Rivers area were usually old hunting cabins and dugouts. However, within a year after their arrival, houses began to appear. The choice of a building site and of a settlement as a whole was determined based on a number of conditions: the presence of fertile land as well as proximity to water, to the forest, and to grazing sites for livestock. As with the Eastern Transbaikal, the origin point of the bulk of settlers, the Priargun'ie Three Rivers region is not uniform in terms of its landscape. In this region one may find forest, forest-steppe, and steppe zones. Each of these zones offered distinctive features for settlers selecting a place of residence.

The beginning of construction, its separate stages and completion, the moving in of residents, and also, of course, the life of the family are accompanied by a whole series of rituals. However, in relation to the Russian house of the Three Rivers area, unfortunately, we have at our disposal extremely scanty material. The current residents of this region of northern Manchuria that identify with Russian culture and with the Russian world, but that hardly remember anything of the history of the former Russian settlements. This gap in their knowledge is even more true of rituals that accompanied the erection of a new house. While I was conducting field research, I heard from only one informant that such rituals had taken place. It is telling that this testimony came from a "pure Russian" babushka [lit. grandmother, used to mean elderly woman], Taisia 
Nikolaevna Petuhkova. She was born in 1931 in China and, having married a Chinese man, she never left the region. In answer to my repeated inquiries about Russian houses and their construction, she could only tell me that Russians "choose a place, look it over, and then, [...] so that everything will be all right, so that everything will be peaceful, they raise the beams, and then when the beams are raised, $[\ldots]$ they celebrate, $[\ldots]$ and set out a meal."

This short account shows that for Russian inhabitants of Priargun'ie, the selection of the site for a house had an important meaning, so much so that one of the key moments in its construction was the raising of beams which was obligatorily accompanied by a ritual meal, most likely with the participation of not only the future owners and laborers but also neighbors and relatives who came to help, as was generally characteristic in Transbaikal (Ignatovich 2009: 118; Solovieva 2011: 130). I was unable to discover whether Russians from the Three Rivers area traditionally placed money in the foundations of the house or sacrificed a rooster or some other domestic animal at the time of the construction. To this day, in the Russian territory of the Priargun'ie, people place money under the beam when building a house, garage, or bathhouse, as attested to in records from the towns of Nerchinskii Zavod and Gorbunovka, NerchinskoZavodskii District and in the town of Zargol, Priargunskii district, Zabaikalskii region (2).

While visiting former Russian settlements in the Three Rivers area, one constantly catches oneself looking for traces of the Russians who had once lived there. The first thing that draws one's attention is the large quantity of log houses in the villages. However, a significant portion of them were built after the Russians had already left the Three Rivers area. Their architectural features include the interior floor plan, the number and placement of window openings, the size of the house, and the use of a $\mathrm{kan}$ (a traditional Chinese stove) in place of an oven. All of these features distinguish modern houses in the Three Rivers settlement from old Russian buildings. They have but one thing in common: the use of logs as the principal building material. Based on the comments of the descendants of mixed ethnicities of the Russians that I met, the Chinese learned how to build with logs from the Russians.

Nevertheless, Old Russian houses are still found in the Three Rivers area. In literally every formerly Russian settlement, one may discover two or three houses, and sometimes more, that had been built by Russians. However, because they are so dilapidated, they are completely abandoned, they are used as farm buildings, or they house very poor Chinese people who do not have the resources to build new houses for themselves. I was able to visit some of them and to see the mute witnesses of the vanished Russian way of life, including the ring that held the cradle, the inner lintels, and the shelves in the icon corner.

The characteristic features of the "real" Russian house in the Three Rivers area include carved lintels on the windows and ornamentation on the facade. In terms of their subject matter, the designs are repetitive. While one could blame the poor preservation of the "Russian" house for this impression, in my opinion, the lack of diversity and expression in the ornamentation of the house corresponds to the ornamentation in the Russian Priargun'ie, which is equally as nonexpressive. (3) It seems that the Transbaikal Cossacks and Russian peasants brought their woodcarving tradition with them from the territory bordering China from the 1920 s to the 1930 s.

Another prominent feature of the Russian house are the shutters. However, this element is practically never found in the Three Rivers area now, even in those houses that were built by "pure" Russians. During the Cultural Revolution, people began removing shutters that prevented outsiders from seeing what was happening inside. Shutters continue to be used only on public buildings such as stores.

Of all the rituals connected with the house, the most well-known among the Chinese 
Russians (4) of the Three Rivers area is the custom of "asking permission from the domovoi" [house spirit, spirit master] when moving in. Home-owners almost everywhere in this region still preserve the memory of this spirit much more so than other similar characters of folk mythology such as the bannik [bathhouse spirit], leshii [forest spirit], vodianoi [water spirit], and rusalka [forest nymph]. (5)

We find the earliest accounts of belief in the domovoi (also called sosedka, busedka) among the inhabitants of Eastern Transbaikal in Konstantin Loginovskii's work Materials toward an Ethnography of the Transbaikal Cossacks (1903: 4-6). He remarks that the head of the household must maintain good relations with the susedko to keep peace in the home, asking his permission when moving to a new house, and baking him special flat breads once a year. Loginovskii also includes a number of bylichki [memorates] about meetings with the domovoi.

Note that the data recorded from Chinese Russians of the Three Rivers area quite often relate to the past, not to the present; as a rule, they have heard about the domovoi and all other spirits, the hosts of house buildings, the yard, and the kitchen garden, from their parents. It seems that only in the single settlement of Hulun'buirskii Aimak, in Karavannaia (Chinese name Enhe), (6) does belief in the domovoi persist, and rituals to honor it are performed to this day. In connection with the process of moving in, respondents mentioned the domovoi as a rule, implementing a formula when addressing him:

To dedushka-sosedushka they say, 'Dedushka-sosedushka let me stay not one night but rather for ages and ages.' That is pretty much all. Lina told me that earlier" (Tat'iana Vladimirovna Fomina).

When you move into the izba, into a new house, you ask the domovoi's permission, 'Let us live there not one day nor two but for ages and ages!' They say something like that. Uh-huh (Nina Ivanovna Gregorieva).

Domovoi, let me live here. They [placed] bread, threw salt in the four corners. They asked the domovoi's permission, 'Domovoi-master, allow me to live here.' Well, that's what I say. It used to be that old people all asked permission like that" (Galina Matveevna Pakharukova).

But even if you are putting up a new izba, you still have to ask permission to move in. They go and get an icon, they get some bread. Then they go and ask his permission, 'Lord master, let us into our house.' And then the whole family goes in and eats" (Mariia Aleksandrovna Makarova).

According to the latter two accounts about entering a new house and addressing the domovoi, the people brought along bread, salt, and icons. This practice was recorded in greater detail in the village of Karavannaia, where, as I noted above, the custom exists to this day. Anna Antonovna Mikhaleva, born in 1932, a "pure" Russian women who, having married a Chinese man and having had children, stayed in China, said that, when moving into a new house, people ask for permission, "Lord domovoi, Lord, Lord, Lord master, allow us to move into the house." She added, "I also went into my $i z b a$, brought bread, brought salt, and icons. I went in with icons."

Interesting texts about addressing the domovoi were also recorded from Marusia 
Dementeva, born in 1941, and from Anna Baliabina, born in 1947. Both are of mixed ethnicity and both apparently have performed the ritual a number of times. According to M. Dementeva,

We always go into the new izba, we always ask permission. They say the domovoi is the master. My grandmother always used to say, then mama would say, 'If you are moving in, bake some kind of prianiki [spice cookies] or something and hide them away somewhere. Then say, 'Domovoi, well, dedushka. Let us in to live here. And watch over all my children so that they will be healthy, and alive and well, and able to work.' This is how they ask him, and then they put [the cookies] down. That is how we do it as well.

Anna Baliabina described a similar tradition:

Whenever my children move in somewhere, I always ask permission from the domovoi [...] I go in with bread and salt, I ask permission: 'Allow it, domovoi, accept my children, save my children. Give them happiness!' I put out some bread and some salt and carry in the icon. [...] You go into the house, then you put the icon up [in the icon corner], then you ask for permission and put bread and salt there. Then, when our children move in and they are cooking there for the first time, then they eat the bread and salt.

In response to the question of whether people leave special, baked buns for the domovoi and where, she answered, "In the corners, [...] all four corners, [...] on the day when you ask for his permission, on that day! [...] And that's it."

The difference in these local residents' formulas for addressing the domovoi can be explained, it would seem, by the fact that in their families, no one except them, neither the husbands nor the children nor the grandchildren, still speaks Russian. Thus, the rest of the family, when requesting the domovoi's permission, says the words in Chinese. In an interview with M. Dementeva, she noted,

I sometimes say it in Chinese, too. I say it in both Russian and also in Chinese, 'Master (we call him master) [...] Master, let us in here, well, to live, and give our children goodness and health. May they always be healthy and earn good money. May all live thus. Live so all is well. May they be rich.' [...] In Chinese we call him zhuren, zhuren. 'Zhuren, Rang women de haizi haohao guo rizi, rang tamen shenti jiankang, baoyou tamen. Master of the house, let our children live well, may they have good health, God keep them.'

The formula for addressing the domovoi has clearly transformed under the influence of the Chinese language. "In Chinese, you know, they also ask for permission," said A.A. Mikhaleva, "In Chinese they have that rule, too. They call him chuzhen. We call him master, but they say chuzhen." It is possible that the Russian babushka understood Chinese in this case to mean both people of mixed ethnicities and native Chinese people living in Karavannaia. In any case, this "rule" was most likely borrowed from the Russians, as M. Dementeva reported, "The Chinese also, the locals, we tell them [how to address the domovoi when moving into the new house], and they do it in Chinese." However, a respondent from Karavannaia who would only identify herself as "Anna" (mixed ethnicity, born 1949), reported a slightly different formula for addressing the domovoi in Chinese: "Qiu shen baoyou, baoyou women lai zheli, zhu changjiu. I 
ask God to protect us, bless our journey here, I wish it to be forever." It is characteristic that this formula was pronounced during the Chinese ritual of moving into the house. According to the words of the respondent: "Now the children, they speak Russian poorly and understand little. When they move in, the sons [put] their shoes in first. He's the master! [...] [They leave their shoes] near the bed or under the bed. [...] Well, that's what they have in mind, but they don't speak [Russian], that they have come to a new house." Anna here differentiates between the Chinese ritual, which she performs when her children, who speak exclusively Chinese and in reality already identify as Chinese, move into a house, and the ritual that she performed for herself, as a Russian, "Wherever we move, we ask permission from the domovoi. We ask permission. Wait. I forgot the first word. I remembered the end: 'Let us sleep here not one night, nor spend one day, but for ages and ages' [...] And we move in like Russians. Bread, salt, icons, and then we ask permission from the domovoi. The icons come first." T.V. Fomina, a resident of Popirai, also related that she performs this ritual on behalf of her children when they move into a new house,

My children got married, the girls left, the boys got married, and I went as well, asked permission from dedusha-sosedushka. If you are Russ... [apparently, she wanted to say "Russians," but for some reason she hesitated, author's note], or half-bloods even, you just have to do it. I went [and did it]. The children just don't understand! Of course! And they speak Chinese more and more!

This ritual apparently remains especially meaningful in Karavannaia, which is not surprising, considering the status of the village, which is now developing a tourist industry and as a result, is attempting to preserve its "Russian" identity. Marusia Dementeva, in addition, did not just tell me about the ritual but showed me an offering to the domovoi that was had been made when people moved into a new house-hotel. (7)

You saw how we arranged everything there? People are moving in, it is a hotel. I also went and asked permission. There wasn't space to put [an offering] down. They [the builders] plastered the walls, but I didn't see it. So that's why I stuck it there on the shelf. No one can get up there. So, I put it there. [...] I bought prianiki, I put them there, no one will get them down. I threw them that far.

An additional, interesting detail of the ritual was reported by Granny Marusia's sister, Nina Dementeva (mixed ethnicity, born 1934), "When we move into the izba, you have to put up the icon and bring salt. What next? Then kneel facing the stove, bow here. 'Domovoi master, allow us into this house! Here let us not stay one night, let us stay for ages and ages! Don't touch us or bother us. We won't touch you either."”

Chinese Russians still remember that if they do not ask permission from the domovoi, then the homeowners or their children will get sick, and their livestock will die out (reported by I.V. Vasil'ev, and N. Dementeva, village of Karavannaia; M.A. Makarova, village of Ernishnoe;). In addition, they will begin to see into the world of the supernatural, according to Ania, village of Ernishnoe. It is interesting that comparatively young (30-40 years of age) people of mixed ethnicity do not accept this belief, as Ania told me, "We move in and live normally, we do not see anyone. What would we see? Someone thought this up, someone with a sick mind thinks like that. It just seems to be the case to him. It's just, he thinks like that." 
In sum, the ritual, which is now known and performed only by a few people of mixed ethnicity in the Three Rivers area, typically has only one form: people ask permission from the domovoi when they move into a new house. K.D. Loginovskii (1903: 5) describes this practice, "When moving to a new house, they pour a shot-glass of vodka and say: 'Dedushka, sosedushka, come live with us.' As for the glass, first they bring it into the new house and place it in the oven, where they also put a flat bread that they baked just for him." From the $19^{\text {th }}$ century to the beginning of the $20^{\text {th }}$ century, the inhabitants of Transbaikal, the ancestors of these ChineseRussians, would first invite the domovoi to come with them from their old house. Modern inhabitants of Transbaikal who live on the Russian side of Priargun'ie still know this alternate form of the ritual and do invite the domovoi from the old house and thus bring it to the new residence. The modern inhabitants of Priargun'ie, both on the Russian and the Chinese sides, have forgotten that vodka was offered to the domovoi. In the present form of the rite, they simply invite the domovoi-master to come with them. According to N. Dementeva, "And since we're now moving from here, we will invite him along with us. We were living here. [...] That is how we moved, the domovoi master moves with us."

Along with asking permission from the domovoi, the residents of Karavannaia have preserved another tradition: blessing the house with holy water. They bring water and icons up to the Mount of Ascension on the $40^{\text {th }}$ day following Easter, and there they wash the icons in the water, which becomes holy. (8) M. Dementeva describes this practice as follows,

When I went into the hotel for the first time this year, it had to be blessed. We blessed it too. [...] We sprinkle [water with] bird cherry branches, or something else. You just can't use aspen! Aspen, they say, is cursed. We can break branches from a bird cherry or a birch tree, and sprinkle [...] the whole house, in the corners, the whole house.

The interpenetration of Russian and Chinese culture in the lives of people of mixed ethnicity in the Three Rivers region occurs at all levels: material, spiritual, and ritual. The rituals for the erection of a new house are no exception. For example, the Chinese ritual for a newly built house, a practice that is still observed by the descendants of Russian-Chinese marriages. People describe setting off rockets, i.e., fireworks, and also attaching red fabric to the house and to the gate as well. I witnessed this rite in 2010, when the completion of a new "Russian" hotel was celebrated in Karavannaia. According to T.N. Petukhova, yet other "Chinese" rituals take place, for example, when raising house beams, "Only Chinese people attach red fabric [to the beam]. They take candy, and they boil eggs, and they throw them on the ground. [...] And the Russians do the same, the ones that were here, they raise beams. There you go. The most important thing is the beams."

Interactions with the domovoi-master were to be maintained by members of the household as long as they lived in the house. K.D. Loginovskii (1903: 4-5) notes that rites of appeasement were performed by the Transbaikal Cossacks in the $20^{\text {th }}$ century,

For peace in the home and the well-being of animals, it was important for the masters to maintain good relations with the susedushka; thus once a year they make him flat bread and leave it in the pechurka [a small recess in the stove], under the floor, or in the stables and the cattle yards.

This rite was at one time practiced in the Three Rivers area as well, judging by the 
account of M. A. Makarova, a woman from the village of Ernishnoe. She said,

Then at Epiphany they put that piece of bread in the four corners. They say that the domovoi would eat it. At Epiphany our mother would take a piece of bread, go into the cellar, and put it there. And I would say, 'Who are you doing that for?' She says, 'Let the domovoi eat it.' She watches out for him. I don't know if it's right. But right now we don't do it for anyone. We just live normally. We don't do it for anyone.

Although she did not remember the name of the holiday, T.N. Petukhova also described this practice,

You know, Russians still baked these bublichki [bagels] out of flour. And then they put in them in the cellar for the domovoi. [...] Yes, yes, yes, they leave them in the basement! That's for the domovoi! [...] That is how it always is with the Russians, always, and see, however long you're there, maybe a half a year, maybe a year will pass, again they will bake these buns, and they will lay them out again.

In the Russian territory of Priargun'ie, this tradition, it would seem, has also been preserved, although in a modified form. In in an elderly woman's house in the village of Dano in 2008, I was shown candies lying on the cabinet, the weekly gift for the domovoi. (9)

Speaking with the Chinese Russians of the Three Rivers area about the domovoi, I, of course, asked whether anyone had seen him, in which situations, what he looked like, and so forth. An overwhelming majority of those asked answered that he cannot be seen. We collected only two accounts of the appearance of the domovoi. According to G.M. Pakharukova from Verkh-Kuli, her nephew, who currently lives in Russia, once saw the domovoi in the form of an old man with big, blue eyes. She said that,

He appeared to my nephew, who now lives in Ulan-Ude. He was laying down, sleeping on the floor, when he opened his eyes he saw someone lying there [...] An old man. His eyes, he says, are blue-blue! He says - big eyes, blue! [...] He was frightened, he couldn't move, hands and feet were numb, he couldn't move. But suddenly he disappeared. And he didn't know where he went. Then he could move his hands and feet.

Another account, that of A. Mikheleva from Karavannaia, is more interesting. She saw the domovoi in the form of an old Tungus man who spoke Chinese. This event took place in her daughter's house. Her daughter had married a Chinese man. Mikheleva described the event as follows,

I spent the night at my daughter's place in Siratui, at my second daughter's, she is dead now. And I lay down on the bed, I had slept on that bed before, and now I was laying there and I saw in a dream that an old man was standing there. The old man is standing there just like that, like a Tungus anyway, with a beard like they have, he stood in front of me and said, [...] 'O, Lord, who is that lying in my spot?' In Chinese, he says: 'O! Tin na! Shi shei tifan to shila? (10) Who is it that took my spot?' He was speaking Chinese! And I jumped up, and then said: 'O, Lordy, oi, I say, Lord, Lord domovoi master, I say, it's me, I lay down in your place, I say, I acted wrong, I didn't ask for permission, I didn't 
ask your permission and lay down in this place.' [...] But I answered him in Russian.

In response to my question about why the domovoi spoke Chinese, Anna Antonovna answered, "So he speaks Chinese! She [the daughter] was married to a Chinese man! This is his place!" This response indicates that that, since the house was Chinese, the domovoi must be as well.

In general it would appear that, according to the Russians of the Three Rivers area, life in a Chinese house was unsafe. According to T. N. Petukhova, "My sister always told me you shouldn't buy a Chinese house, it's dangerous." In fact, she had personal experience with this situation, since her older sister Taisiia Nikolaevna's house, where a Chinese man had lived, was haunted. She told the following story about the house.

We lived in Chistaia, I was not married yet. But I had an older sister, she's been dead for a long time. I went to visit her. Well, I was young, she had a son, Stepan, he was also young. We ran, we played, came home and laid down to sleep and didn't hear anything. One time on New Year's we were running, playing, my sister fell asleep. She was waiting for us and she fell asleep. And I ran in, and I laid down to sleep. Then I heard a rattling at the back of the izba. Even the dish cupboard was shaking! It was real, I know that. I jumped from my bed onto my sister's bed! She said: 'O, it's nothing, nothing, nothing, nothing!' She lit the fire right away. 'Don't be afraid, don't be afraid, don't be afraid! It's a cat,' she said, 'it must have climbed in.' She didn't tell us anything. Nothing. One time she went out. I forgot where she and my brother-in-law went. She left an old lady with us, to sit with us. But it was already ten at night, and they still hadn't come back. Then a rattling began at the back of the izba. Ooo! We jumped out of there with a shriek. And the old lady was right behind us. 'O, Lord!,' she says. And right away we locked the door and left for her place, for the old lady's place. Then my sister came back. And you know what? Under my sister's fence [they found] a huge Chinese braid. They found such a braid! And in it there was a yellow piece of paper folded up like a flower. Lots of people were there and they all saw it. And they threw this braid into the oven, burned it up. It even crackled, and the oven door flew off to the side. And then it became calm. They say someone had hidden the braid there. [...] And those who bought the house said that a Chinese man with a braid had lived there. [...] My sister and them were talking among themselves, here, they say, one Chinese man lived with a big braid. That's right, they found the braid. And it became peaceful. It's not a lie and not a fairy tale, it's true. I heard it with my own ears. I was shaking with fear on my sister's bed. O, it was scary! I was young then. And it was scary! I asked, 'Niania, what is it?' Everyone called her Niania. I asked, 'Niania, what was the knocking?' 'Nothing, nothing nothing,' she said. 'I'll light the fire right now.' And every time I woke up the fire was still burning. My brother-inlaw was sitting near by, and next time my sister was sitting near by. I saw all this and wondered why they were sitting up. But, since I was young, I turned over and went back to sleep. [...] They were afraid that we children would find out and be frightened. But in the end we found out anyway. [...] They had a little dog! A black one! And it came up to the fence and scratched and scratched. And my sister asked: 'What's it scratching for?' She came closer, and they got up and started pulling out the braid. The dog was so small [and still found the braid]. 
The braid was the most important element of the traditional male hairstyle among Manchurians. Having conquered China in the beginning of the $17^{\text {th }}$ century, the Manchurians forced all the Han Chinese men, under penalty of death, to braid their hair, shaving the front part of the head. Officially men were no longer required to wear braids after the 1911 Sinkhai revolution, but in Manchuria itself this tradition was preserved. The Chinese man with the big braid mentioned in the bylichka may really have cut off his braid and left it in his old house when he moved. However, to the Russians who had found it, this action was interpreted as a clear attempt to spoil the life of the new masters of the home.

Russian houses in the Three Rivers area could be haunted for a another reason as well. Tais'ia Nikolaevna told another bylichka on this topic,

The old ladies told me that they lay down to sleep and they heard knocking, and some heard accordion music and dancing. That's what the old ladies said, but I don't know if it's true or they are lying. And then, they say, it became impossible to live. And someone taught them. When you hear knocking, you have to draw a circle right away around the place where you hear it. And light a fire right away. When you draw a circle, they can't get out. So, they lit a fire, and the doll fell [out]. Someone had hidden a doll [in the house]. That's what the doll did!

Interestingly, to the Russians and people of mixed ethnicities in the Three Rivers area, all the stories about unusual events, magic, demons, and the like, seem to have occurred when primarily Russians lived there. As Petukhova remarked, "The old women told us it used to happen a lot. But now nothing's left. Now people have become like demons. They aren't afraid of anything, they've overpowered everything, they've overcome everything!"

While stories about most of the other minor spirits do not occur in stories told by residents of this area, the bannik [bathhouse spirit] was occasionally mentioned in minor ways. People typically mentioned the bannik in connection with the prohibition on washing in the bathhouse after midnight. When asked about the reason for the prohibition, V.I. Gromova reported that "They scared people! [People would scare others] so they wouldn't go to the bathhouse. They scared the girls, scared the young men, 'Don't go to the bathhouse at night.' Young people went to the bathhouse to flirt and make out. So, people scared them!" M.A. Makarova had a similar response, "Well, they scared them, too! [...] They say, 'Don't come to the bathhouse late at night.' They say that a demon lives in the bathhouse. [...]" (And what is this demon's name?) "The bannik!" Finally, A. A. Mikhaleva said that "The bathhouse also has a master - the bathhouse master. They say there is a master in every bathhouse. I don't know. [...] But at midnight you shouldn't go to the bathhouse, they say." M. Dementeva expressed a similar opinion,

But now we wash at midnight. Earlier it wasn't allowed! They say that at midnight demons are out. [...] Always at midnight. They are always out. They crawl out. Well, they walk and somehow fly around. The souls walk around. Midnight is not a good time. That's what people used to say.

The respondent, it seems, had heard a bylichka about a person who went into the bathhouse at midnight. A demon, or as she said 'unclean soul,' started to strangle the person, but the rooster crowed and he was saved. She concluded the story by saying that, "They say that the 
demon, an unclean soul, came. He wanted to do all these bad things, to strangle the man, or something else. The rooster crowed and he [the bannik] ran off." Only one respondent, A. Baliabina, reported that when one first uses a new bathhouse, one should ask permission from the "bathhouse domovoi," "Yes, the first time you go into a bathhouse to heat it up, you must ask permission. [...] As soon as you go in to steam, say, 'Bathhouse domovoi, let us into the bathhouse. Give us happiness, give us health!"' (What you mean by the first time?) "When the bathhouse is used for the first time." Because a single-family bathhouse is rare among Chinese Russians, it is not surprising that the beliefs about the bannik are less common than those about the domovoi.

The history of Russians in the Three Rivers area is tragic in many ways. Their flight from Soviet Russia in the 1920s and 1930s and starting over in a new place from scratch; lack of citizenship, first under the Chinese and then under the Japanese (who forced practically all the Russians near the border to move deeper into China in the early 1930s); the constant threats from the Soviet side, expressed in reconnaissance activities and military raids, which killed civilians. The result, by the late 1950s and early 1960s, was a Russian exodus from the Three Rivers area. The Russian house, both as a material and symbolic object, endured all these events along with its inhabitants. M. Dementeva's amazing story parallels this tragic and disconnected past. Her grandmother and her mother, who was still a young girl, fled from the USSR, apparently from Nerchinskii Zavod, where the grandmother had been born. In China, the grandmother was married a second time to a Chinese man and gave birth to her uncle, Mikhail. Mikhail, in the words of my informant, was a married man "associated with" the Russians, i.e., he gathered intelligence for the Soviet authorities. Apparently, he then fled to the USSR:

First, he got along fine with his father, and then he got drunk once at his father's house and broke the stove apart and ran away, to break any connection with his father. He destroyed everything, and took off on the sleigh. [...] But I only heard about this, people used to say our uncle ran off, broke grandfather's stuff, and ran off. Harnessed the horse, and he took off with the horse, sleigh, and my aunt [...] She's his wife. Her name is Zina.

Her uncle's abandonment of his parents' house was symbolically expressed in his antisocial behavior, especially the destruction of such a semiotically important element as the stove, the heart of the house.

With the departure of the Russians, who had left their houses with all of their other farm buildings, as well as mills, stores, schools, hospitals, churches, these settlements were repopulated by Dungan Muslims from the south by decree of the new Chinese authorities. The houses suffered as a result. The Russian agricultural way of life was unfamiliar to them. According to stories, "the southerners," who had never seen house like these, boarded up the doors and went in and out through the windows; they broke up the floors, did not know how to use the stove, and painted on the clean walls. Such absurd behavior recalls that of characters in Russian fairy tales about a town of fools, and people from the Three Rivers area tell these stories with good humor:

[The settlers] came earlier. In Tuluntui there were Russian houses that belonged to the Kaikov family! They pulled up the floors. They boarded up the doors. They climbed in through the windows. [...] In the izba (among the Russians), people whitewashed the walls, it's clean, it's bright. [The Chinese say] it's bad for your eyes. They paint over the 
walls $[\ldots]$ Now they've learned, they leave the walls white. There was all sorts of stories. (N. Dementeva and P. P. Smolianskii)

Houses were whitewashed with lime. They (the settlers) weren't used to it. And the floor was painted yellow. They weren't used to that either. It ruins the house, they chopped it up so the floor wouldn't be so slippery. But now the old people began to talk about this. They laugh at themselves. You might say that it was all a fairy tale, but it was true." (Baliabin Konstantin)

The contemporary Russian house in the Three Rivers area, a structure combining Russian and Chinese characteristics, is inhabited by descendants of Russian-Chinese marriages, who officially number slightly over four thousand. It contains Russian objects, including: icons on icon shelves, Easter eggs and pussy-willow branches, framed photographs on the walls, benches (which here, as in Transbaikal, are called kanapel), tables, chairs, samovars, nesting dolls, and so forth. However, on the doors and walls hang colorful Chinese gods and Chinese characters made out of paper wishing happiness. In the houses of two familes of mixed ethnicity, I saw talismans acquired in a Buddhist monastery to ward off demons (in Chinese, fue) above the door. I also saw small mirror attached to the facade in A. Baliabina's house, apparently on the initiative of her Chinese daughter-in-law, who believed that "It would be good for the family, so the children would not get sick. She said, 'The door faces the window, that's not good, we need to hang a mirror here.' [...] These are Chinese fears." Only a few houses in families of mixed ethnicity have Russian-style stoves used to bake bread, and the existing ones are only found in outbuildings. Now the need for such stoves, in Karavannaia, for example, has disappeared since a large bakery opened in the village in 2009, and one can buy Russian bread in quantity. In old houses there are traditional Chinese stoves (called kan) rather than Russian ones, and the new houses feature water-heating systems.

With the departure of Russians from the Three Rivers region, the house per se ceased to exist as well. It changed completely and acquired Chinese features. Chinese rituals are now performed during construction and while moving into a new house. The domovoi has started to look like a Tungus and to speak Chinese. Even the owners of the house may address him in Chinese. From inside and out, the house has taken on a Chinese aspect, preserving only isolated elements to remind us of its Russian roots. To paraphrase Spengler, when a type of house disappears it means that a certain "breed of human" has died out as well. In other words, when the people of a particular culture disappear, then the house associated with them, so central to their belief and identity, dies too. We see clear evidence of this phenomenon in the Russian house in the Priargun'ie Three Rivers region.

Translated by Greg Bayles. Special thanks to Dr. Jessica Merrill and Dr. Gabriella Safran for reviewing the original English translation. Transliterations and translations from the Chinese by Dr. Liu Kuili.

\section{NOTES}

1 This article was written with the financial support of the Russian Humanitarian Science Foundation. Project № 14-04-00449.

2 Records of this practice are attested in the Field Archive of the Social- 
Anthropological Research Center, Russian State Humanities University

3 In fact, among the houses in the towns of the Nerchinsko-Zavodskii, Priargunskii, and a few other southeastern districts of the Transbaikal area, in former Cossack settlements (stanitsi) and villages, some of which have two or three-hundred-year-long histories, we almost never see houses with the sort of rich wooden carvings seen in Old Believer villages (semeiskiie) in the western area of Transbaikal (this territory includes the Krasnochikoiskii district) and in neighboring Buriatiia. This relationship to the outer appearance of the house can be explained by the fact that the history of this region was closely tied to exile and hard labor. For those who were exiled here, life was perceived to be only a temporary phase. It seems to me that this fact explains the reluctance to adorn the house.

4 A term that has been used since 1991 in the Chinese document "index of nationalities" to denote an individual who is ethnically part Russian and part Chinese with Chinese citizenship.

5 It should be noted that I happened on a situation where the word itself, domovoi, was understood to mean "relative" by those with whom I was speaking, and they did not know other terms used in the given region for the domovoi, such as susedka [neighbor] or dedushkasusedushka [neighbor-grandfather].

6 Here and henceforth the names of the settlements are given in the form by which they were known from the 1920s to the 1950s.

7 A residence that has been vacated by the owners and rented out to travelers.

8 About this practice, M. Dementeva reported that, "Easter will pass and in forty days is Ascension. We have a hill, there is a cross there, we go there to pray to God. Then we carry out the icon out of the house, carry water from the stream, buckets, and we wash these icons. Everyone does it in that order. Everyone prays, everyone kisses the icons. Then we stand in a line. Then we divide the water and go home."

9 N. Dementeva also reported that, in a parallel to the rite of moving into a new house, the people also ask permission from the domovoi when they bring cattle into the yard for the first time. If this is not done, then the cattle will not thrive.

10 The narrator's Chinese is poor, so that the version given by her is non-standard as a result.

\section{BIBLIOGRAPHY}

Ignatevich, T. Iu. 2009. "Русская картина мира: региональные языковые реализации общенародных доминант" [The Russian Picture of the World: Regional Linguistic Realizations of a Pan-ethnic Pattern]. Ученые записки Забайкальского государственного гуманитарнопедагогического университета им. Н. Г. Черньишевского [Academic Notes of the N. G. Chernyshevskii Transbaikal State Humanities-Pedagogical University], No. 3:117-121.

Jung, C. G. 2003 (1963) Воспоминания, сновидения, размыиления [Memories, Dreams, Reflections]. Minsk: Initsiativa, AST.

Klyaus, V.L. 2010. “Административная реконструкция русской деревни в Китае” [Administrative Reconstruction of the Russian Village in China]. In Сибирская деревня [The Siberian Village], Vol. 3. Omsk: Omsk State University. 234-245. 
Loginovskii, K.D. 1903. "Материалы к этнографии забайкальских казаков" [Materials towards an Ethnography of Transbaikal Cossacks]. Записки общества изучения Амурского края Владивостокского отделения Приамурского отдела РГО [Notes of the Society for the Study of the Amur Region of the Vladivlastok Section of the Priamur Division], Vol. 9, No. 1: 1135 .

Solovieva, M. R. 2011. "Характер отражения традиционных форм крестьянской взаимопомощи в современных устных рассказах русских старожилов Приангарья и Забайкалья." [The Character of the Reflection of Traditional Forms of Peasant Mutual Assistance in Contemporary Oral Narratives of Long-time Russian Residents of the Angara and Transbaikal Region]. Traditsionnaia Kul'tura, No. 1: 126-135.

Spengler, Oswald. 2009 (1922) Закат Европь [The Decline of the West], Vol. 2. Moscow: Mysl.

\section{INTERVIEWS}

Anna [Last Name Unknown], b. 1949, Mixed Ethnicity, Interviewed in 2009, Karavannaia (En'khe)

Baliabin, Konstantin, b. 1960, Mixed Ethnicity, Interviewed in 2007, Karavannaia (En'khe)

Baliabina, Anna, b. 1947, Mixed Ethnicity, Interviewed in 2007, Karavannaia (En'khe)

Dementieva, Marusia, b. 1941, Mixed Ethnicity, Interviewed in 2009, Karavannaia (En'khe)

Dementieva, Nina, b. 1934, Mixed Ethnicity, Interviewed in 2009, Karavannaia (En'khe)

Fomina, Tat'iana Vladimirovna, b. 1945, Mixed Ethnicity, Interviewed in 2007, Popirai (Tian'shi)

Grigorieva, Nina Ivanovna, b. 1937, Mixed Ethnicity, Interviewed in 2007, Shchuch'e (Suchin)

Gromova, Valentina Ivanovna, b. 1932, Mixed Ethnicity, Interviewed in 2007 Labdarin (Erguni)

Makarova, Mariia Aleksandrovna, b. 1930, Mixed Ethnicity, Interviewed in 2007, Ernichnaia (Sap'ian)

Mikhaleva, Anna Antonovna, b. 1932, Russian, Interviewed in 2007, Karavannaia (En'khe)

Pakharukova, Galina Matveevna, b. 1944, Mixed Ethnicity, Interviewed in 2007, Verkh-Kuli (Shankuli)

Petukhova, Taisiia Nikolaevna, b. 1931, Mixed Ethnicity, Interviewed in 2007, Karavannaia (En'khe)

Smolianskii, Petr Ivanovich, b. 1934, Mixed Ethnicity, Interviewed in 2009, Karavannaia (En'khe) 